\title{
Digenetic Trematode Parasites in Two Fresh Water Fishes Ophiocephalus Punctatus and Xenentodon Cancila From North West Himalayas
}

Sukanya Rajput ( $\nabla$ sukanyarajputjmu@gmail.com )

University of Jammu https://orcid.org/0000-0002-2748-5787

\section{Seema Langer}

University of Jammu

\section{Research Article}

Keywords: Trematode, metacercariae, Jammu, digenetic, Ophiocephalus punctatus, Xenentodon cancila

Posted Date: November 17th, 2021

DOI: https://doi.org/10.21203/rs.3.rs-271485/v1

License: ( (1) This work is licensed under a Creative Commons Attribution 4.0 International License. Read Full License

Version of Record: A version of this preprint was published at Journal of Parasitic Diseases on March 6th, 2022. See the published version at https://doi.org/10.1007/s12639-022-01473-7. 


\section{Abstract}

The study was conducted during September 2018-August 2019 to study the digenetic trematode infection in fresh water fishes of some of the water bodies viz. Gho-manhasan, Chakrali and Chadwal of Jammu region of J\&K union territory A total of 220 fishes comprising Ophiocephalus punctatus and Xenentodon cancila belonging to families Channidae and Belonidae respectively were examined. A total of 4 digenetic trematode parasites belonging to 4 different families i.e., Euclinostomum heterostomum (Clinostomidae Luhe, 1901); Phyllodistomum tripathi (Gorgoderidae Looss, 1901); Genarchopsis piscicola (Hemiuridae, Luhe, 1901), and Bucephalopsis karvei (Bucephalidae Poche, 1907) were detected. The overall prevalence of digenetic trematode infection was $65.90 \%$ and the mean intensity was 3.58. Among these Genarchopsis piscicola showed the highest prevalence (40.38\%) with mean intensity 2.95 in the host fish Xenentodon cancila, while in other species the prevalence ranged between $26.23 \%$ and $34.62 \%$. Present study authenticates the presence of several species of digenetic trematode parasites in the fishes inhabiting freshwater of J\&K union territory.

\section{Introduction}

Fish constitutes an important source of food, nutrition, income and livelihood for millions of people around the world. Moreover, fish continues to be one of the most traded food commodities worldwide with more than half of fish exports by value originating in developing countries. Fishes provide a potential habitat to metacercariae of digenetic trematodes. Digenetic trematodes are a diverse group of parasites that use more than one host to complete their life cycle. Avian digenetic trematodes use fishes as secondary intermediate hosts to complete their life-cycles (Bullard and Overstreet 2008). Trematodes are the most diverse group of fish parasite and are present in larval or adult forms in majority of fish species and most of them exist as endoparasites. Digenetic trematode infections cause low weight gain, high mortality and immarketabilty of the infected fish. Currently, fish-borne zoonotic trematodes are the cause of health problems and also affect the public health in many Asian countries (Murrell et al. 2007; Tran et al. 2008; Phan et al. 2010). The present study was therefore undertaken to ascertain the spectrum of digenetic trematodes from fresh water fishes Ophiocephalus punctatus and Xenentodon cancila in Jammu region.

\section{Materials And Methods}

A total of 220 fish samples were collected from different freshwater bodies of Jammu region; Gho-manhasan, Chakrali and Chadwal. Collected fish samples were brought alive to laboratory. The gastrointestinal tract, muscle tissue and other internal organs of the host fish were teased in $0.8 \%$ saline and examined for the recovery of the metacercarial or adult stage oftrematode parasites. Trematode parasites were flattened between two slides or under slight pressure of slide and coverslip, post-fixed in AFA (Alcohol, Formalin and Acetic acid in 85:10:5) and stained with Borax carmine. Afterwards, specimens were dehydrated in ascending series of ethanol, cleared in xylene and finally mounted on glass slides using DPX. Photomicrographs of stained specimens were studied and photographed using microscope Leica M205 C and identified by following the standard literature (Yamaguti 1971; Bray et al. 2008; Pandey and Agrawal, 2013). The prevalence of infection and mean intensity were calculated following Bush et al. (1997).

No. of hosts infected

Prevalence $=-\times 100$

Total no. of hosts examined

No. of parasites recovered

Mean Intensity $=$

Total no. of infected hosts

\section{Results \& Discussion}

Based on morphological and morphomertic criteria the recovered trematode parasites were identified as belonging to genera Euclinostomum (Rudoliphi, 1809) Travassos, 1928 (Family Clinostomiodae Luhe, 1901); Phyllodistomum Braun, 1899 (Family Gorgoderidae Looss, 1901); Genarchopsis Ozaki, 1925 (Family Hemiuridae (Looss, 1899, Luhe, 1901) and Bucephalopsis Diesing, 1855 (Family: Bucephalidae Poche, 1907) all of which are redescribed .

1. Euclinostomum heterostomum (Rudolphi, 1806) Travassos, 1928 (Figa) 
Host: Ophiocephalus punctatus Bloch

Site of infection: Liver, Coelomic cavity, muscles

Locality: Gho-manhasan, Chakrali

Prevalence: $33.62 \%$ (39 infectedout of 116 host)

Mean intensity: 4.68 (182 parasites were recovered from 39 infected host)

\section{Description}

Cysts of E. heterostomum were yellowish and spherical, excretory vesicle, intestinal caeca brownish and are observed on the external surface; excysted metacercariae body elongated, linguiform after fixing measures 4.36-6.54mm×2.18-2.49mm; anterior end of the body truncated and posterior end is rounded; oral sucker sub-terminal, small surrounded by collar-like fold $0.19-0.38 \mathrm{~mm} \times 0.16-0.27 \mathrm{~mm}$; ventral sucker lager well developed, almost round measuring 0.712-0.872 mm×0.625-0.721 mm; Pharynx rudimentary; oesophagus short bifurcates in front of acetabulum; intestinal caeca long with 7-12 lateral diverticulate branching; anterior testis U-shaped 0.115-0.159x 0.36-0.462mm ; posterior testis Y-shaped $0.218-0.320 \times 0.253-0.374 \mathrm{~mm}$; cirrus sac oval, intertesticular; ovary small, round to oval, intertesticular 0.121 $0.146 \times 0.140-1.28 \mathrm{~mm}$; uterine sac elongated and club shaped; excretory pore subterminal.

\section{Remarks}

The genus Euclinostomum was established by Travassos, 1928 which have well developed diverticulated ceaca. Moreover, Euclinostomum is the type genus of subfamily Euclinostominae, found in the buccal cavity and in the oesophagus of piscivorous birds, primarily herons and egrets. Many reports of metacercarial and adult forms of E.heterostomum from freshwater fishes have been studied by several workers across the world (Jhansilakshmibai \& Madhavi 1997, Britz et al. 1984, Taher 2009, Purivirojkul and Sumontha 2012, Suanyuk et al. 2013, Senapin et al. 2014, Abro et al. 2016, Mansour 2019) from different host fishes. Present fluke exhibits similarities with E.heterostomum Rudolphi, 1809, E.bhagavantami Jaiswal, 1957, E.minutus Bhutta and Khan, 1975 and E.reticulatum Sudan, 1979 (Table no.2). In the present fluke oral sucker is subterminal closely resembles to E.reticulatum but smaller than E.bhagavantami and E.minutus. The number of intestinal diverticulae differs in E.bhagavantami (9-12), in E.minutus (12-15) whereas resembles E.reticulatum with 7-12 diverticula. The size of ovary, however show resemblance to E.minutus which is quite smaller than that of E.bhagavantami and E.reticulatum. Thus the present fluke differs from E.bhagavantami, E.minutus and E.reticulatum in body size, size of ovary and testes. The present form closely resembles Euclinostomum heterostomum in size and shape of body and various organs which is reported from host fish Ophiocephalus punctatus of Jammu region.

\section{Phyllodistomum tripathi Motwani \& Srivastava, 1961 (Fig.b)}

Host: Xenentodon cancila Hamilton

Site of infection: Intestine

Locality: Chadwal

Prevalence: $34.62 \%$ (36 infected out of 104 host)

Mean intensity: 2.83 (102 parasites were recovered from 36 infected host)

\section{Description}

Body dorsoventrally flattened, spatulate 1.58-3.72mm long, 0.72-2.04mm maximum width at level of middle region of hindbody; fore-body narrow, elongated $0.89-0.94 \mathrm{~mm} \times 0.43-0.75 \mathrm{~mm}$; hind-body expanded nearly with feebly developed semicircular puckering present on the lateral sides of hind body, 0.95-0.98mm×0.78-0.80mm in size; oral sucker terminal, oval 0.19-0.26×0.20-0.28mm; ventral sucker rounded, pre-equatorial slightly larger and wider than oral sucker $0.22-0.28 \mathrm{~mm} \times 0.24-0.33 \mathrm{~mm}$;prepharynx and pharynx absent; oesophagus straight, narrow $0.12-0.17 \mathrm{~mm}$ long bifurcates into well developed two intestinal caeca which terminate close to hind body end; testes deeply lobed, intercaecal, post-ovarian ; right testis post-equatorial 0.16-0.20×0.14-0.17mm; left testis equatorial 0.22-0.24×0.18-0.20mm; gential pore median, pre-acetabular; ovary submedian, lobed, pretesticular, 0.07-0.12mm $\times 0.06-0.08 \mathrm{~mm}$; two compact vitelline glands, right vitelline gland $0.06-0.07 \mathrm{~mm} \times 0.03-0.04 \mathrm{~mm}$ and left vitelline gland $0.07-0.08 \mathrm{~mm} \times 0.04-0.05 \mathrm{~mm}$; eggs oval, non-operculate $0.02-0.03 \times 0.01-0.02 \mathrm{~mm}$. 


\section{Remarks}

The genus Phyllodistomum was erected by Braun (1899) for Distomum folium Olfers, 1816 as its type species. Based on the narrow and tubular anterior region and spatulated hind body our specimen belonged to the genus Phyllodistomum. Different species of the genus Phyllodistomum have been reported by several workers (Cribb, 1987; Helt, 2003; Mendoza-Garfias et al. 2005; Ho et al. 2014) from fishes all over the world including that from India (P.loossi Kaw, 1950; P. indianum Jaiswal, 1957; P. tripathi Motwani and Srivastava, 1961; P. srivastavi Rai, 1964; P. cameroni Agarwal, 1966; P.megacotyle Fotedaar, 1969; P.mansari Sudan, 1979; P. triangulata Sarwat, 2011; P.betwaensis Sen, 2014; P.punctatai Jithila and Prasadan, 2018). The present species resembles with P.loossi in the relative size of suckers, shape and position of vitellaria, uterus and genital pore. It however differs in the absence of any papillae in suckers and the size of eggs which are smaller and more slender in present form. The present species shows similarities with P.betwaensis but different from P.betwaensis in size of body, size of oral and ventral sucker and position of Vitelline glands with respect to ovary (Table no. 3). The present species differ further from P.punctati, a species reported from urinary bladder of Channa punctata in ratio of body length to width, size of oral and ventral sucker and various morphological and morphometry features. Present species resembles P.tripathi in having the lateral margins of hindbody provided with indentations, however differs in some morphological features and morphometry like length to width ratio of body, size and shape of ventral sucker and size of testes and ovary. Since, most of the characteristics of the present species bear a close resemblance with P.tripathi hence the identified as P.tripathi reported from freshwater fish Xenentodon cancilla of Jammu.

\section{Genarchopsis piscicola Srivastava, 1933 (Fig.c)}

Host: Xenentodon cancilla Hamilton

Site of infection: Stomach

Locality: Chakrali, Chadwal

Prevalence: $40.38 \%$ (42 infected out of 104 host)

Mean intensity: 2.95 (124 parasites were recovered from 42 infected host)

\section{Description}

Body cylindrical, more or less fusiform, 1.28-2.57×0.42-0.79mm; oral sucker oval, sub-terminal 0.24-0.38×0.26-0.47mm; ventral sucker equatorial, highly muscular and well developed $0.56-0.79 \times 0.58-0.80 \mathrm{~mm}$; prepharynx absent; pharynx 0.03-0.07×0.09-0.12mm; oesophagus absent; testes two, roughly triangular or oval in outline, extracaecal; right testis $0.16-0.17 \times 0.12-0.14 \mathrm{~mm}$; left testis $0.15-0.17 \times 0.13-0.14 \mathrm{~mm}$; pars-prostatica tubular and well developed; metraterm absent; genital pore present below pharynx near intestinal bifurcation; ovary 0.13 $0.18 \times 0.09-0.15 \mathrm{~mm}$ posttesticular, oval, median or dextrally placed between testes and vitelline glands two, oval, compact $0.15-0.20 \times 0.08-$ 0.012mm; eggs oval, operculated bear long filaments $0.032-0.035 \times 0.009-0.016 \mathrm{~mm}$.

\section{Remarks}

The genus Genarchopsis was erected by Ozaki (1925) with G. goppo as the type species from the intestine of Mogurnda obscura, Japan. Several species of Genarchopsis have been reported viz. G. ovocaudata Srivastava, 1933 from Ophiocephalus punctatus; G. piscicola Srivastava, 1933 from Channa punctatus; G. anguillae Yamaguti, 1938 from Anguilla japonica G. folliculate Bhadauria and Dandotia, 1954 from Mastacembelus sp. and Channa sp.; G. thapari Dwivedi, 1965 from Bufo melanostictus; G.punctati Agarwal, 1966 from Ophiocephalus punctatus; G. cameroi Kakaji, 1969 from Mystus seenghala; G. cuchiai Kakaji, 1969 from Amphipnous cuchia; G. avitellarium Varma and Sahay, 1983 from Ophiocephalus punctatus; G. kalriai Bilqees and Khan, 1990 from Channa marulius; G.fellicola Shimazu, 1995 from Rhinogobius brunneus; G.gibsoni Shaikh et al., 2011 from Opiocephalus striatus. The present parasite resembles closely with G. piscicola, G.goppo and G.gibsoni (Table no. 4). The present form differ markedly from Ozaki's species G.goppo in larger body size, size and ratio of suckers, position of genital pore, absence of oesophageal pouch, location of gonads, position of vitellaria and position of ventral sucker. It differs from G.gibsoni in various morphological features and morphometry in body size, size of oral and ventral sucker, position and shape of testes and ovary. But the present form shows comes very close to G.piscicola in position of oral sucker, size and ratio of suckers, absence of oesophagus, shape and disposition of testes and position of gential pore. The present species is redescribed as G.piscicola and reported from different host Xenentodon cancila of Jammu region.

4. Bucephalopsis karvei Bhalerao, 1937 (Fig.d)

Host: Xenentodon cancila Hamilton 
Site of infection: Intestine

Locality: Chadwal

Prevalence: $26.93 \%$ (28 infected out of 104 host)

Mean intensity: 3.92 (110 parasites were recovered from 28 infected host)

\section{Description}

Body small pear-shaped with broader anterior end and a pointed posterior end measuring $0.57-0.98 \mathrm{~mm} \times 0.31-0.52 \mathrm{~mm}$; tegument covered with spines; rhynchus (anterior sucker) large, spherical, terminal, 0.11-0.23mm×0.13-0.20mm; pharynx muscular, oval 0.05-0.06mm×0.04$0.07 \mathrm{~mm}$; esophagus tubular opens into digestive cecum; cecum globular sac-like, median $0.06-0.09 \mathrm{~mm} \times 0.06-0.01 \mathrm{~mm}$; testis oval, unequal, anterior testis $0.12-0.14 \mathrm{~mm} \times 0.08-0.09 \mathrm{~mm}$, posterior testis $0.11-0.13 \mathrm{~mm} \times 0.07-0.09 \mathrm{~mm}$; cirrus sac cylindrical, extent from level of testis to posterior of body $0.24-0.28 \mathrm{~mm} \times 0.05-0.07 \mathrm{~mm}$; pars prostatica opens into short ejaculatory duct; ovary oval, pre-testicular, $0.06-0.08 \times 0.07$ 0.09mm; egg numerous oval, 0.017-0.018×0.009-0.012mm.

\section{Remarks}

Diesing (1855) erected Bucephalopsis as subgenus of Bucephalus Von Baer, 1827 for Bucephalus hairreanus Lacaze-Duthiers, 1834 and was later raised to full generic status by Laebour (1908). Srivastava and Chauhan (1973) treated Bucephaloidea as a junior synonym of Prosorhynchoides and transferred Bucephaloides sp. to the Genus Prosorynchoides based on the presence of simple sucker (rhynchus) and a pretesticular ovary in it. Several species of Genus Bucehalopsis (Prosorynchoides) have been reported from India; these include P.fusiformis (Verma, 1936) Srivastava and Chauhan 1973; P.garuai Verma, 1936; P.magnum Verma, 1936; P.karvei (Bhalerao, 1937) Srivastava and Chauhan 1973; P.thapari (Dayal, 1948) Bott and Cribb, 2005. Maurya et .al., (2018) synonymized P.lateroporus, P.gaurii, P.chauhani, N.(P.) jhansiansis and P.canciliansis with P.karvei. The present form belongs to the genus Bucephalopsis Diesing, 1855 . Bhalerao (1937) reported B. karvei from the intestine of Xenentodon cancila. The present adult worms were also recovered in large number from the intestine of Xenentodon cancila and closely resemble B.karvei in body shape, position of testes and ovary, but differ in some morphological and morphometric characters. The present adult worms differs from P.garuai, P.fusiformis and B. thapari in various morphological and morphomertic characters size and shape of body, size of rhynchus, position of ovary and testes and also size and disposition of cirrus sac and uterus (Table no.5). This bucephalid is new locality record observed for the first time in Jammu region, J\&K.

\section{Declarations}

Conflict of interest: The authors declare that there is no conflict of interest.

Ethical approval: No approval by an ethical committee was required to achieve the goals of the present study.

\section{References}

1. Abro MM, Dharejo AM, Khan MM, Birmani NA (2016) Euclinostomum heterostomum (Rud., 1809) Travassos, 1928 (Trematode: Clinostomidae: Euclinostominae): A new record in avian host little cormorant (Aves: Phalacrocoracidae) of Pakistan. Journal of advances in Biology and Biotechnology 8(1):1-5

2. Bhalerao GD (1937) Studies on the Helminths of India. Trematoda IV Jour Helminth 15:97-124

3. Bhutta SM, Khan D (1975) Digenetic trematodes of vertebrates from Pakistan. Bulletin of Department of Zoology, University of Punjab (New Series). Pk ISSN, 0079-8045

4. Bray RA, Gibson DI, Jones A (2008) Keys to the Trematoda, vol 3. Natural History Museum, CABI, UK

5. Britz J, Saayman JE, Van JG (1984) Anatomy of the metacercaria and adult of Euclinostomum heterostomum (Rudolphi, 1809) (Trematoda: Clinostomatidae). South African Journal of Zoology 19(2):91-96

6. Bullard SA, Overstreet RM (2008) Digeneans as enemies of fishes. In: Eiras JC, Segnar H, Wahli T, Kapoor BG (eds) Fish diseases, vol 2. Science Publishers, Enfield, pp 817-976

7. Bush AO, Lafferty KD, Lotz JM, Shostak AW (1997) Parasitology meets ecology on its own terms: Margolis et al. revisited. J Parasitol 83:575-583

8. Cribb TH (1987) A new species of Phyllodistomum (Digenea: Gorgoderidae) from Australian and New Zealand freshwater fishes with notes on the taxonomy of Phyllodistomum Braun, 1899. J Nat Hist 21:1525-1538

Page 5/12 
9. Diesing KM (1855) Neuzehn arten von Trematoden. Akademie Wissenschaften in Wien Mathematisch Naturwissenschaftliche Klass $32: 307-390$

10. Gupta BK (2011) O On some metacercariae and adult trematodes of fishes. Ph.D. Thesis submitted to University of Lucknow, Lucknow.

11. Helt J, Janovy J, Ubelaker J (2003) Phyllodistomum funduli n. sp. (Trematoda: Gorgoderidae) from Fundulus sciadicus cope from cedar creek in western Nebraska. J Parasitol 89(2):346-350

12. Ho HW, Bray RA, Cutmore SC, Ward S, Cribb TH (2014) Two new species of Phyllodistomum Braun, 1899 (Trematoda: Gorgoderidae Looss, 1899) from Great Barrier Reef fishes. Zootaxa 3779:551-562

13. Jaiswal GP (1957) Studies on the trematode parasites of fishes and birds found in Hyderabad State. Part I-IV. Zool Jber 85:1-72

14. Jhansilakshmibai K, Madhavi R (1997) Euclinostomum heterostomum (Rudolphi, 1809) (Trematoda): life-cycle growth and development of the metacercaria and adult. Sys Parasitol 38:51-64

15. Jithila PJ, PK Prasadan (2018) Prevalence, intensity, mean abundance and description of Phyllodistomum punctati n. sp. (Digenea: Gorgoderidae) from the urinary bladder of Channa punctata (Bloch) from the Western Ghats, India. Int J Fish Aquat Stud 6:01-05

16. Kaw BL (1950) Studies in Helminthology: Helminth parasites of Kashmir. Part- I Trematoda. Ind J Helminth 2:67-126

17. Mansour RM (2019) First record of Euclinostomum heterostomum from the naturally infected heron Aredeola ralloides in Egypt: A light and scanning electron microscopy. Egyptian Journal of Zoology (EJZ) 72:22-31

18. Maurya R, Gupta R, Saxena AM (2018) Taxonomic redescriptions and a review of the status of Prosorhynhoides spp. (Digenea; Bucephalidae) infecting some freshwater fieshes of India

19. Mendoza-Garfias B, de Perez-Ponce G (2005) Phyllodistomum centropomi sp. n. (Digenea: Gorgoderidae), a parasite of the fat snook, Centropomus parallelus (Osteichthyes: Centropomidae), in the Papaloapan River at Tlacotalpan. Veracruz State, Mexico Zootaxa 1056:43-51

20. Motwani MP, Srivastava CB (1961) On two Phyllodistomum from urinary bladder of siluroid fishes (Trematoda: Gorgoderidae). Indian J Helminthol 13:93-99

21. Murrell KD, Fried B (2007) World class parasites, vol. 11. Food-borne parasitic zoonoses. Fish and plant-borne parasites. Springer, New York, NY

22. Ozaki Y (1925) On a new genus of fish trematodes, Genarchopsis, and a new species of Asymphylodora. Japanese Journal of Zoology 1:101-108

23. Pandey KC, Agrawal N (2013) Metacercarial Fauna of India, Rec. zaol. Surv. India, Gcc. Paper No., 349: 1-310, (Published by the Director, Zool. Surv. India, Kolkata)

24. Phan TV, Ersboll AK, Bui TQ, Nguyen HT, Murrell D, Dalsgaard A (2010) Fish-borne zoonotic trematodes in cultured and wild-caught freshwater fish from Red River delta, Vietnam. Vector Borne Zoonotic Dis. 10:861-6Suppl 9

25. Purivirojkul W, Sumontha M (2012) Euclinostomum heterostomum (Rudolphi, 1809) Metacercarial infection in three osphronemid fish species walailak. Journal of Science and Technology 10(1):97-102

26. Rudolphi CA (1809) Entozoorum sive vermium intestinalium. Historia naturalis. 1, (Amsteold.)

27. Sarwat MS (2011) A new species of genus Phyllodistomum (Braun, 1899), (Digenea: Gorgoderidae, Looss, 1901) from freshwater fish Mastacembelus armatus Aurangabad (M.S.) India. Recent Res Sci Technol 3:11-13

28. Sen JM (2014) On a New Species of Phyllodistomum Braun, 1899 (Digenea: Gorgoderidae), A Parasite of Freshwater Fish, Channa Punctatus (BL.) From Betwa River, Bundelkhand Region Jhansi, U.P, India. Current World Environment. ; 9(1):207-209

29. Senapin S, Phiwasaiya K, Laosinchai P, Kowasupat C, Ruenwongsa P (2014) Phylogenetic analysis of parasitic trematodes of the genus Euclinostomum found in Trichopsis and Betta fish. J Parasitol 100:368-371

30. Shaikh GS, Khan A, Bilqees FM (2011) A new trematode of the genus Genarchopsis Ozaki, 1925 from freshwaterfish of Sindh, Pakistan. Pakistan J Zool 43(5):903-907

31. Srivastava HD (1933) On new trematodes of frogs and fishes of the United provinces, India Part I Distomes of the family: Hemiuridae from North Indian Fishes and frogs and a systematic discussion on the family Halipegidae and the Genera Vitellotrema Guberlet and Genarchopsis Ozaki. Bull Acad Sci U P Agra Oudh Allahabad 3(1):41-60

32. Suanyuk N, Mankhakhet S, Soliman H (2013) Euclino-stomum heterostomum infection in guppies Poecilia reticulata cultured in southern Thailand. Dis Aquat Organ 104(2):121-127

33. Sudan OS (1979) O Studies on trematode fauna of Jammu Province. Ph.D. Thesis submitted to the University of Jammu

34. Taher GA (2009) Some studies on metacercarial infection in Oreochromis niloticus in Assiut Governorate and their role in transmission of some trematodes to dogs. Ass Univ Bull Environ Res 12:63-79

Page 6/12 
35. Tran TKC, Dalsgaard A, Turnbull JF, Tuan PA, Murrell KD (2008) Prevalence of zoonotic trematodes in fish from a Vietnamese fishfarming community. J Parasitol 94:4238

36. Yamaguti S (1971) Synopsis of digenetic trematodes of vertebrates, vol 1. 2. Keigaku, Tokyo

\section{Tables}

Table 1: Digenetic trematodes recovered, their host, site of collection and prevalence of infection from Jammu region.

\begin{tabular}{|c|c|c|c|c|c|c|c|c|}
\hline \multirow[t]{2}{*}{$\begin{array}{l}\text { Name of Host } \\
\text { Fish }\end{array}$} & \multirow[t]{2}{*}{$\begin{array}{l}\text { Name of parasites } \\
\text { recovered }\end{array}$} & \multirow[t]{2}{*}{$\begin{array}{l}\text { Site of host } \\
\text { collection }\end{array}$} & \multirow[t]{2}{*}{$\begin{array}{l}\text { Site of } \\
\text { infection }\end{array}$} & \multicolumn{2}{|c|}{$\begin{array}{l}\text { Number of Host } \\
\text { Fish }\end{array}$} & \multirow{2}{*}{$\begin{array}{l}\text { No. of } \\
\text { parasites } \\
\text { recovered }\end{array}$} & \multirow{2}{*}{$\begin{array}{l}\text { Prevalence } \\
(\%)\end{array}$} & \multirow[t]{2}{*}{$\begin{array}{l}\text { Mean } \\
\text { intensity }\end{array}$} \\
\hline & & & & Examined & Infected & & & \\
\hline $\begin{array}{l}\text { Channa } \\
\text { punctatus } \\
\text { Bloch }\end{array}$ & $\begin{array}{l}\text { Family: Clinostomidae } \\
\text { Luhe, } 1901 \\
\text { Euclinostomum } \\
\text { heterostomum }\end{array}$ & $\begin{array}{l}\text { Gho- } \\
\text { manhasan, } \\
\text { Chakrali } \\
\text { stream }\end{array}$ & $\begin{array}{l}\text { Liver, } \\
\text { Coelomic } \\
\text { cavity, } \\
\text { muscles }\end{array}$ & 116 & 39 & 182 & 33.62 & 4.68 \\
\hline \multirow{5}{*}{$\begin{array}{l}\text { Xenentodon } \\
\text { cancila Hamilton }\end{array}$} & $\begin{array}{l}\text { Family: } \\
\text { Gorgoderidae Looss, } \\
1901 \\
\text { Phyllodistomum } \\
\text { tripathi }\end{array}$ & $\begin{array}{l}\text { Chadwal } \\
\text { stream }\end{array}$ & Intestine & 104 & 36 & 102 & 34.62 & 2.83 \\
\hline & $\begin{array}{l}\text { Family: Hemiuridae } \\
\text { Luhe, } 1901 \\
\text { Genarchopsis pisicola }\end{array}$ & $\begin{array}{l}\text { Chakrali \& } \\
\text { Chadwal } \\
\text { stream }\end{array}$ & Stomach & 104 & 42 & 124 & 40.38 & 2.95 \\
\hline & $\begin{array}{l}\text { Family:Bucephalidae } \\
\text { Poche, } 1907\end{array}$ & $\begin{array}{l}\text { Chadwal } \\
\text { stream }\end{array}$ & Intestine & 104 & 28 & 110 & 26.93 & 3.92 \\
\hline & Buchephalosis sp. & & & & & & & \\
\hline & & & & 220 & 145 & 518 & 65.90 & 3.58 \\
\hline
\end{tabular}

Table 2: Comparative measurements of Euclinostomum heterostomum with other species of Euclinostomum (in mm). 


\begin{tabular}{|c|c|c|c|c|c|}
\hline Characters & $\begin{array}{l}\text { E. } \\
\text { bhagavantami } \\
\text { (Ukoli, 1966) }\end{array}$ & $\begin{array}{l}\text { E. minutus } \\
\text { (Bhutta and } \\
\text { Khan, 1975) }\end{array}$ & $\begin{array}{l}\text { E.reticulatum (Pandoh, } \\
\text { 1992) }\end{array}$ & $\begin{array}{l}\text { E.heterostomum } \\
\text { (Purivirojkul and Sumontha } \\
\text { 2013) }\end{array}$ & $\begin{array}{l}\text { E. heterostomum } \\
\text { Present species }\end{array}$ \\
\hline $\begin{array}{l}\text { Mean body } \\
\text { size }\end{array}$ & $12.7 \times 3.37$ & $\begin{array}{l}4.484- \\
6.66 \times 1.66-2.424\end{array}$ & $6.40-10.08 \times 1.76-3.26$ & $5.78-7.77 \times 2.25-2.73$ & $\begin{array}{l}4.36-6.54 \times 2.18- \\
2.49\end{array}$ \\
\hline Oral sucker & $0.53 \times 0.38$ & $\begin{array}{l}0.235- \\
0.302 \times 0.245- \\
0.392\end{array}$ & $0.19-0.32 \times 0.24-0.48$ & $0.199 \times 0.264$ & $\begin{array}{l}0.19-0.38 \times 0.16- \\
0.27\end{array}$ \\
\hline Ventral sucker & - & $\begin{array}{l}0.235- \\
0.392 \times 0.245- \\
0.39\end{array}$ & $0.96-1.47 \times 0.96-1.76$ & $0.978 \times 0.930$ & $\begin{array}{l}0.712- \\
0.872 \times 0.625- \\
0.721\end{array}$ \\
\hline $\begin{array}{l}\text { Number of } \\
\text { diverticula }\end{array}$ & $9-12$ & $12-15$ & $6-13$ & $10-12$ & $7-12$ \\
\hline Ovary & $0.6 \times 0.26$ & $\begin{array}{l}0.245- \\
0.333 \times 0.235- \\
0.393\end{array}$ & $0.09-0.20 \times 0.08-0.24$ & $0.179 \times 0.149$ & $\begin{array}{l}0.121- \\
0.146 \times 0.140-1.28\end{array}$ \\
\hline Anterior testes & - & - & $0.48-1.20 \times 0.08-0.24$ & $0.13 \times 0.179$ & $\begin{array}{l}0.115-0.159 x \\
0.36-0.462\end{array}$ \\
\hline $\begin{array}{l}\text { Posterior } \\
\text { testes }\end{array}$ & - & - & $0.40-1.12 \times 0.19-0.40$ & $0.530 \times 0.680$ & $\begin{array}{l}0.218-0.320 x \\
0.253-0.374 \mathrm{~mm}\end{array}$ \\
\hline Hosts & - & Bird & Channa punctatus & $\begin{array}{l}\text { Trichopsis vittata, Betta } \\
\text { splendens, Betta imbellis }\end{array}$ & $\begin{array}{l}\text { Ophiocephalus } \\
\text { punctatus }\end{array}$ \\
\hline Locality & - & Pakistan & Jammu (J\&K) India & Israel & $\begin{array}{l}\text { Jammu (J\&K) } \\
\text { India }\end{array}$ \\
\hline
\end{tabular}

Table 3: Comparative measurements of Phyllodistomum tripathi with other species of Phyllodistomum (in mm). 


\begin{tabular}{|c|c|c|c|c|c|}
\hline Characters & $\begin{array}{l}\text { P.tripathi } \\
\text { Motwani \& Srivastava, } \\
1961\end{array}$ & $\begin{array}{l}\text { P.cameroni } \\
\text { Agrawal, } 1966\end{array}$ & $\begin{array}{l}P \text {. betwaensis } \\
\text { Sen, } 2014\end{array}$ & $\begin{array}{l}\text { P.punctati } \\
\text { Jithila \& } \\
\text { Prasadan, } 2018\end{array}$ & $\begin{array}{l}\text { Present } \\
\text { Species } \\
\text { P.tripathi }\end{array}$ \\
\hline Mean body size & $1.55-4.58 \times 0.74-2.02$ & $4.23 \times 2.23$ & $\begin{array}{l}1.4-1.6 \times 0.41- \\
0.43\end{array}$ & $\begin{array}{l}1.54-6.13 \times 1.03- \\
4.32\end{array}$ & $\begin{array}{l}1.58-3.72 \times 0.72- \\
2.04\end{array}$ \\
\hline $\begin{array}{l}\text { Length to width ratio } \\
\text { of body }\end{array}$ & $2.22: 1$ & $1.89: 1$ & $3.57: 1$ & $1.48: 1$ & $1.92: 1$ \\
\hline Fore-body & $0.9-2.7 \times 0.53-0.8$ & $1.8 \times 1.10$ & $\begin{array}{l}0.81- \\
0.83 \times 0.19-0.21\end{array}$ & $\begin{array}{l}0.62-2.57 \times 0.63- \\
2.16\end{array}$ & $\begin{array}{l}0.89-0.94 \times 0.43- \\
0.75\end{array}$ \\
\hline Hind-body & $0.69-2.0 \times 0.74-2.02$ & $2.52 \times 2.23$ & $\begin{array}{l}0.61- \\
0.63 \times 0.41-0.43\end{array}$ & $\begin{array}{l}0.89-4.00 \times 1.31- \\
4.32\end{array}$ & $\begin{array}{l}0.95-0.98 \times 0.78- \\
0.80\end{array}$ \\
\hline Oral sucker & $0.19-0.50 \times 0.19-0.45$ & 0.5 & $\begin{array}{l}0.15- \\
0.17 \times 0.11-0.13\end{array}$ & $\begin{array}{l}0.33-0.82 \times 0.35- \\
0.76\end{array}$ & $\begin{array}{l}0.19-0.26 \times 0.20- \\
0.28\end{array}$ \\
\hline Ventral sucker & $0.3-0.6$ & 0.5 & $\begin{array}{l}0.23-25 \times 0.17- \\
0.19\end{array}$ & $\begin{array}{l}0.28-0.77 \times 0.35- \\
0.76\end{array}$ & $\begin{array}{l}0.22-0.28 \times 0.24- \\
0.33\end{array}$ \\
\hline Esophagus & $0.11-0.45$ & $0.19 \times 0.08$ & $\begin{array}{l}0.09- \\
0.11 \times 0.03-0.05\end{array}$ & $\begin{array}{l}0.06-0.37 \times 0.05- \\
0.08\end{array}$ & $0.12-0.17$ \\
\hline $\begin{array}{l}\text { Anterior testis (Right } \\
\text { testis) }\end{array}$ & $0.20-0.48 \times 0.20-0.60$ & $0.53 \times 0.40$ & $\begin{array}{l}0.13-0.15 \times 0.1- \\
0.12\end{array}$ & $\begin{array}{l}0.12-0.52 \times 0.07- \\
0.32\end{array}$ & $\begin{array}{l}0.16-0.20 \times 0.14- \\
0.17\end{array}$ \\
\hline $\begin{array}{l}\text { Posterior testis (Left } \\
\text { testis) }\end{array}$ & $0.25-0.55 \times 0.20-0.50$ & $0.44 \times 0.42$ & $\begin{array}{l}0.11- \\
0.130 \times 0.08- \\
1.0\end{array}$ & $\begin{array}{l}0.09-0.68 \times 0.11- \\
0.33\end{array}$ & $\begin{array}{l}0.22-0.24 \times 0.18- \\
0.20\end{array}$ \\
\hline Ovary & $0.10-0.25 \times 0.09-0.25$ & $0.42 \times 0.30$ & $\begin{array}{l}0.09- \\
0.11 \times 0.06-0.08\end{array}$ & $\begin{array}{l}0.11-0.43 \times 0.11- \\
0.37\end{array}$ & $\begin{array}{l}0.07-0.12 \times 0.06- \\
0.08\end{array}$ \\
\hline Right vitelline gland & $0.03-0.12 \times 0.11-0.31$ & $0.10 \times 0.028$ & $\begin{array}{l}0.08- \\
0.01 \times 0.03-0.05\end{array}$ & $\begin{array}{l}0.09-0.29 \times 0.06- \\
0.27\end{array}$ & $\begin{array}{l}0.06-0.07 \times 0.03- \\
0.04\end{array}$ \\
\hline Left vitelline gland & $0.03-0.10 \times 0.11-0.32$ & $0.1 \times 0.029$ & $\begin{array}{l}0.05- \\
0.07 \times 0.02-0.04\end{array}$ & $\begin{array}{l}0.09-0.32 \times 0.05- \\
0.30\end{array}$ & $\begin{array}{l}0.07-0.08 \times 0.04- \\
0.05\end{array}$ \\
\hline Eggs & $\begin{array}{l}0.0512-0.0752 \times 0.0259- \\
0.0492\end{array}$ & $\begin{array}{l}0.0391-0.0522 x \\
0.0194-0.0325\end{array}$ & $\begin{array}{l}0.02- \\
0.04 \times 0.01-0.02\end{array}$ & $\begin{array}{l}0.020- \\
0.029 \times 0.012-0.20\end{array}$ & $\begin{array}{l}0.02-0.03 \times 0.01- \\
0.02\end{array}$ \\
\hline Host & $\begin{array}{l}\text { Bagarius yarrellii } \\
\text { Pseudeutropius garua }\end{array}$ & Rita rita & $\begin{array}{l}\text { Channa } \\
\text { punctatus }\end{array}$ & Channa punctatus & $\begin{array}{l}\text { Xenentodon } \\
\text { cancila }\end{array}$ \\
\hline Location & Lucknow & Lucknow & Jhansi & Western Ghats & Jammu \\
\hline
\end{tabular}

Table 4: Comparative measurements of Genarchopsis pisicola with other species of Genarchopsis.

Table 5: Comparative measurements of Bucephalopsis (Prosorhynchoides) karvei with other species of Bucephalopsis (Prosorhynchoides) 


\begin{tabular}{|c|c|c|c|c|}
\hline Characters & $\begin{array}{l}\text { Genarhopsis piscicola } \\
\text { Srivastva, } 1933\end{array}$ & $\begin{array}{l}\text { Genarchopsis goppo Ozaki, } \\
1925 \\
\text { Described by Shimazu, } 1995\end{array}$ & $\begin{array}{l}\text { Genarhopsis gibsoni } \\
\text { Shaikh et al., } 2011\end{array}$ & $\begin{array}{l}\text { Present species } \\
\text { Genarchopsis } \\
\text { piscicola }\end{array}$ \\
\hline $\begin{array}{l}\text { Mean body } \\
\text { size }\end{array}$ & $3 \cdot 3-3 \cdot 4 \times 1-12$ & $0.99-1.68 \times 0.38-0.61$ & $1.74-1.77 \times 0.65-0.67$ & $\begin{array}{l}1.28-2.57 \times 0.42- \\
0.79\end{array}$ \\
\hline Oral sucker & $0 \cdot 33-0 \cdot 34$ & $0.10-0.17 \times 0.12-0.21$ & $0.25-0.27 \times 0.27-0.29$ & $\begin{array}{l}0.24-0.38 \times 0.26- \\
0.47\end{array}$ \\
\hline $\begin{array}{l}\text { Ventral } \\
\text { sucker }\end{array}$ & $0 \cdot 66-0 \cdot 68$ & $0.23-0.42 \times 0.22-0.42$ & $0.55-0.59 \times 0.47-0.49$ & $\begin{array}{l}0.56-0.79 \times 0.58- \\
0.80\end{array}$ \\
\hline Oesophagus & absent & oesophageal pouch present & absent & absent \\
\hline Testes & $\begin{array}{l}\text { oval, situated a little obliquely } \\
\text { behind acetabulum, extracaecal }\end{array}$ & $22-0.30 \times 0.12-0.23$ & $0.06-.07 \times 0.15-0.16$ & $\begin{array}{l}\text { right testis } 0.16- \\
0.17 \times 0.12-0.14 ; \\
\text { left testis } 0.15- \\
0.17 \times 0.13-0.14\end{array}$ \\
\hline Ovary & $\begin{array}{l}\text { situated inter-caecally to the } \\
\text { right, close behind right testis }\end{array}$ & $0.05-0.15 \times 0.05-0.11$ & $0.06-0.09 \times 0.06-0.08$ & $\begin{array}{l}0.13-0.18 \times 0.09- \\
0.15\end{array}$ \\
\hline $\begin{array}{l}\text { Vitelline } \\
\text { glands }\end{array}$ & $\begin{array}{l}\text { Vitellaria consist of two large, } \\
\text { compact glands, situated } \\
\text { asymmetrically in the extreme } \\
\text { posterior end }\end{array}$ & $0.08-0.16 \times 0.04-0.09$ & $\begin{array}{l}\text { Vitellaria consist of two } \\
\text { very small, dark, } \\
\text { elongate masses } 0.021- \\
0.032\end{array}$ & $\begin{array}{l}\text { vitelline glands } \\
\text { two, oval, } \\
\text { compact } 0.15- \\
0.20 \times 0.08-0.012\end{array}$ \\
\hline Eggs & $\begin{array}{l}0.048 \times 0.015 \text { with a polar } \\
\text { filament, } 0.04 \text { long }\end{array}$ & $\begin{array}{l}51-65 \times 24-30 \text { with opercular } \\
\text { filament present, measuring up } \\
\text { to } 1.20\end{array}$ & $\begin{array}{l}0.006-0.008 \times 0.004- \\
0.006\end{array}$ & $\begin{array}{l}0.032- \\
0.035 \times 0.009- \\
0.016\end{array}$ \\
\hline Genital pore & $\begin{array}{l}\text { Genital pore situated ventrally, at } \\
\text { the level of pharynx }\end{array}$ & $\begin{array}{l}\text { Genital pore usually opening } \\
\text { wide but rarely puckered, } \\
\text { median to submedian, ventral } \\
\text { to pharynx }\end{array}$ & $\begin{array}{l}\text { Genital opening at the } \\
\text { level of posterior margin } \\
\text { of the pharynx }\end{array}$ & $\begin{array}{l}\text { genital pore } \\
\text { present below } \\
\text { pharynx near } \\
\text { intestinal } \\
\text { bifurcation }\end{array}$ \\
\hline Hosts & Ophiocephalus punctatus & Mogurnda obscura & $\begin{array}{l}\text { Channa (Ophiocephalus) } \\
\text { striatus }\end{array}$ & $\begin{array}{l}\text { Xenentodon } \\
\text { cancila }\end{array}$ \\
\hline Locality & Allahabad & Japan & Keenjhar Lake, Pakistan & Jammu, J\&K \\
\hline
\end{tabular}

(in $\mathrm{mm}$ )

Figures 


\begin{tabular}{|lllll|}
\hline Characters & $\begin{array}{l}\text { Prosorhynchoides garui } \\
\text { (Verma, 1936) }\end{array}$ & $\begin{array}{l}\text { P.fusiformis } \\
\text { (Verma, 1936) }\end{array}$ & $\begin{array}{l}\text { P.karvei } \\
\text { (Bhalerao, 1937) }\end{array}$ & $\begin{array}{l}\text { P.karvei } \\
\text { Present species }\end{array}$ \\
\hline Body size & $5.73-6.20 \times 1.38-1.90$ & $1.24-2.52 \times 0.39-0.84$ & $0.5-0.96 \times 0.27-0.57$ & $0.57-0.98 \times 0.31-0.52$ \\
\hline $\begin{array}{l}\text { Rhynchus (anterior } \\
\text { sucker) }\end{array}$ & $0.56-0.69 \times 0.58-0.69$ & $0.17-0.24 \times 0.18-0.24$ & $0.16-0.24 \times 0.142-0.227$ & $0.11-0.23 \times 0.13-0.20$ \\
\hline Pharynx & $0.25-0.29 \times 0.25-0.33$ & $0.07-0.08 \times 0.07-0.084$ & $0.044-0.06 \times 0.044-0.06$ & $0.05-0.06 \times 0.04-0.07$ \\
\hline Cecum & $0.75-1.26 \times 0.21-0.50$ & $0.21-0.46 \times 0.18-0.23$ & $0.68-0.09 \times 0.68-0.09$ & $0.06-0.09 \times 0.06-0.01$ \\
\hline Anterior testis & $0.71-0.86 \times 0.38-0.66$ & $0.18-0.29 \times 0.17-0.26$ & $0.108-0.120 \times 0.082-0.09$ & $0.12-0.14 \times 0.08-0.09$ \\
\hline Posterior testis & $0.58-0.67 \times 0.42-0.54$ & $0.16-0.25 \times 0.15-0.21$ & $0.108-0.120 \times 0.082-0.09$ & $0.11-0.13 \times 0.07-0.09$ \\
\hline Cirrus sac & $0.60-0.92 \times 0.30-0.35$ & $0.46-0.71 \times 0.10-0.14$ & $0.23-0.29 \times 0.056-0.063$ & $0.24-0.28 \times 0.05-0.07$ \\
\hline Ovary & $0.46-0.67 \times 0.29-0.42$ & $0.14-0.21 \times 0.15-0.19$ & $0.056-0.082 \times 0.056-$ & $0.06-0.08 \times 0.07-0.09$ \\
\hline Eggs & $0.023-0.028 \times 0.015-$ & $0.013-0.023 \times 0.008-$ & $0.018-0.002 \times 0.009-$ & $0.017-0.018 \times 0.009-$ \\
\hline Host & 0.017 & 0.015 & 0.013 & 0.012 \\
\hline Location & Silonia silondia & Eutropiichthys vacha & - & Xenentodon cancila \\
\hline
\end{tabular}


a
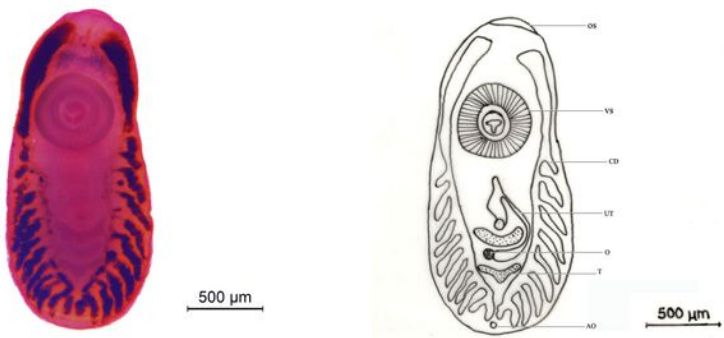

b
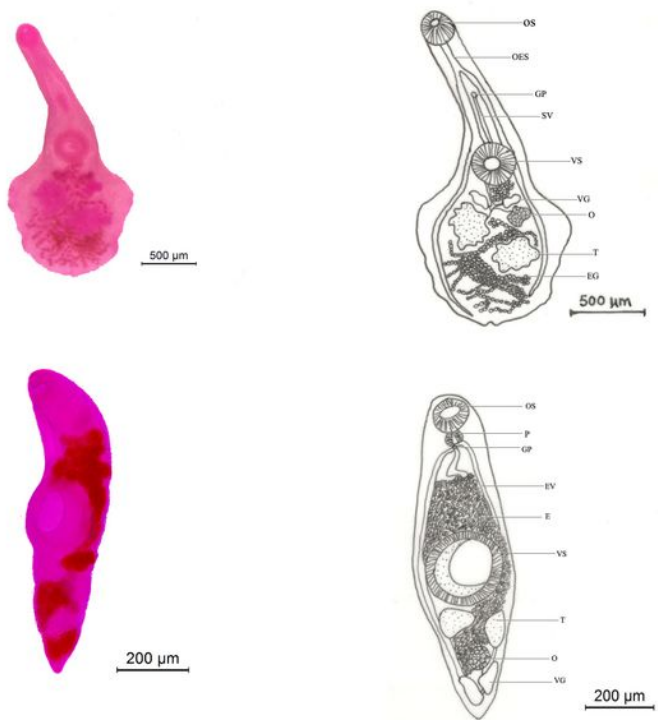

d

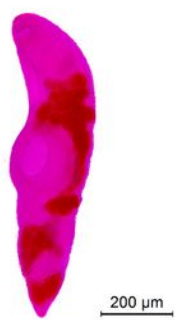

$200 \mu \mathrm{m}$
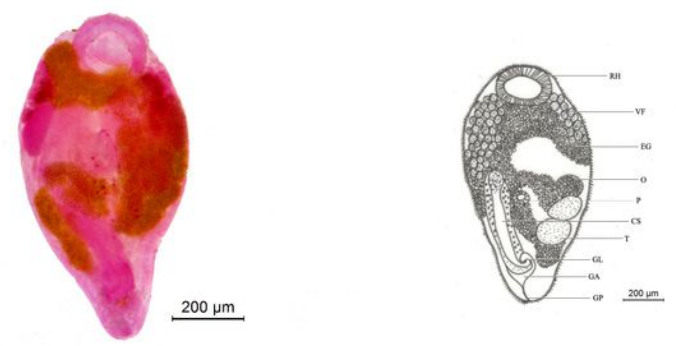

Figure 1

a. Euclinostomum heterostomum (Rudolphi, 1806) Travassos, 1928. b. Phyllodistomum tripathi Motwani \& Srivastava, 1961. c. Genarchopsis piscicola Srivastava, 1933. d. Bucephalopsis karvei Bhalerao, 1937 